\title{
ÓRIÁSPLAKÁT KÖRÜLI LÉGMOZGÁS NUMERIKUS SZIMULÁCIÓJA
}

\section{NUMERICAL SIMULATIONS OF AIRFLOW AROUND BILLBOARDS}

\author{
Milchiș Tudor ${ }^{1}$, Gobesz F.-Zsongor ${ }^{2}$ \\ ${ }^{I}$ Kolozsvári Müszaki Egyetem, Építömérnöki Kar, Tartószerkezetmechanikai \\ Tanszék, 400027, Románia, Kolozsvár, Gh. Barițiu u. 25, II. em., 193, \\ Tel.+40-264-401257,tudor.milchis@mecon.utcluj.ro \\ ${ }^{2}$ Kolozsvári Müszaki Egyetem, Építömérnöki Kar, Tartószerkezetmechanikai \\ Tanszék, 400020, Románia, Kolozsvár, C. Daicoviciu u. 15, III. em., 305, \\ Tel.+40-264-401351,go@mecon.utcluj.ro
}

\begin{abstract}
The most important load on tall rectangular billboards located near main roads is from wind. In case of assemblies made from 2 or 3 pannels, the horizontal shape of the structure will be a triangle. The design prescriptions and standards needed in order to dimension such structures are not covering all the aspects of wind action. For that reason, a numerical simulation of the wind action was performed in Abaqus CAE on the upper part of a billboard made from 3 large pannels.
\end{abstract}

Keywords: wind-load, airflow, turbulent, numerical, simulation, CFD

\section{Összefoglalás}

A fơútvonalak mentén található magas téglalap alakú óriásplakátok esetében e legfontosabb terhelés a szélből származik. Amennyiben 2 vagy 3 panelt szerelnek össze, fentről nézve egy háromszög alakú szerkezet lesz. Az ilyen szerkezetek szélteherre való méretezéséhez szükséges tervezési szabványok és elő́rások hiányosak. Ebből az okból kifolyólag egy numerikus szimulációt végeztünk Abaqus CAE alatt, egy olyan óriásplakát szélből eredő terhelésére, melyet 3 nagy panelböl szereltek össze.

Kulcsszavak: szélteher, áramlat, turbulens, numerikus, szimuláció, CFD

\section{Bevezetés}

$\mathrm{Az}$ óriásplakátok felülete általában négyszögü, igen jelentős méretekkel. Tartószerkezetük leginkább acélból készül, mivel az acél könnyebben szerelhető mint a vasbeton és tartósabb a fánál. A jó láthatóság miatt az informáló felület a magasba kerül, így e karcsú szerkezetek elég nagy széltehernek vannak kitéve.

A szél hatását többen is vizsgálták, a szakirodalomból csupán néhány, általunk fontosabbnak tartott munkát említünk meg. A számításainkhoz Smith és társainak a kutatásai ([1], [2]) nyújtottak kiindulási pontot. Elöttük, Letchford [3] a téglalap alakú panelek méretarányai és áttörtségi hányada szerint végzett átfogóbb vizsgálatokat, míg Shademani és társai [4] kiterjedtebben tanulmányozták a háromszögü óriásplakát szerkezetek viselkedését a szél hatására, a Reynolds szám különböző értékeire (1,4 és 38,03 között, melyek a lamináris légáramlást jellemzik). 
Háromszögü meg V alakú konfigurációkra Agrwal és társai közöltek frissebb szélcsatornás kísérleti eredményeket [5]. Bár az ilyen óriásplakátok egyre népszerübbek Romániában is, a szerkezetre ható erők nincsenek elég részletesen tárgyalva a hazai tervezési elöírásokban („Eurocode 1"-ként is emlegetett SR EN 1991 1-1-4 és CR 1-14-2012) az említett alakzatokra.

A szerkezetek vizsgálatát csupán a felső részre végeztük, ahol a nagyméretü reklámfelületek vannak. Mivel ezeknél a részeknél a Reynolds szám nagyon nagy $\left(10^{6}\right.$-on nagyságrendü), a légáramlás igen magas tubulenciával fog történni, ezért indokolt és szükséges egy térbeli CFD (Computational Fluid Dynamics) modell alkalmazása. A numerikus eljárások ilyen esetekben komoly erőforrásokat igényelnek az elfogadható pontossághoz.

\section{Modellezés és eredmények}

A folyadékokban lévő testekre gyakorolt dinamikus hatást három alapelv határozza meg: a tömeg-megmaradás (vagy folytonosság, 2. egyenlet), az energiamegmaradás (3. egyenlet), és a gyorsulás egyenes aránya a testre ható erővel (4. egyenlet). Összenyomhatatlan folyadékok esetében (ahol $\nabla$ a Laplace féle operátor, 1. egyenlet) $\nabla \cdot \vec{v}=0$.

$$
\begin{aligned}
& \nabla=i \frac{d}{d x}+j \frac{d}{d y}+z \frac{d}{d z} \\
& \frac{\delta \rho}{\delta t}+\nabla \cdot(\rho \cdot \vec{v})=0 \\
& \rho\left(\frac{\partial E}{\partial t}+\vec{v} \cdot \nabla E\right)=\nabla \cdot K_{H} \nabla T-p \nabla \cdot \vec{v} \\
& \rho\left(\frac{\partial \vec{v}}{\partial t}+\vec{v} \cdot \nabla \vec{v}\right)=-\nabla p+\mu \nabla^{2} \vec{v}+\rho g
\end{aligned}
$$

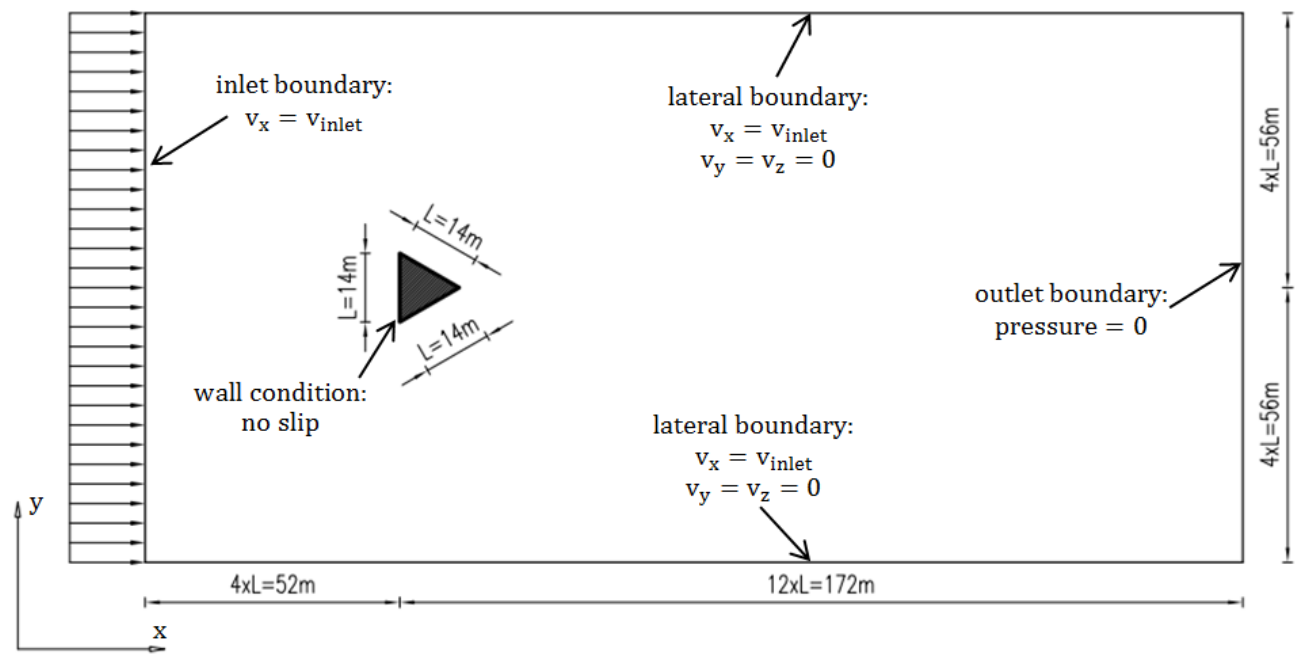

2. ábra. A tanulmányozott test a vizsgálati tartományban és a tartomány peremfeltételei. 
A 2.-4. egyenletekben $\rho$ a folyadék sürüsége, $\vec{v}$ a sebesség vektora, $p$ a nyomás, $\mu$ a folyadék viszkozitása, $E$ a belső energia, $K_{H}$ a hővezetési együttható és $T$ a hömérséklet. A fenti egyenletek egy nem-lineáris parciális deriváltakat tartalmazó egyenletrendszerhez vezetnek, melyek NavierStokes neveivel közismertek.

A numerikus modellhez $5 \mathrm{~m}$ magas paneleket vettünk (1. ábra), így a vizsgálati tartomány magasága $15 \mathrm{~m}$ lett. $\mathrm{E}$ térbeli tartomány méretei és peremfeltételei a 2. ábrán láthatók.

Három mesterséges szélsebesség-változási diagrammot használtunk, melyeket a Bielecki és társai [6] által leírt eljárással generáltunk 600 másodperces időtartammal és $34,73 \mathrm{~m} / \mathrm{s}$ maximális szélsebességgel.
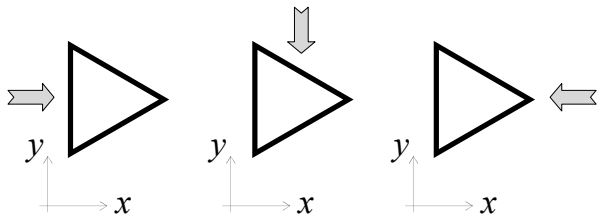

3. ábra. A három terhelési eset (a szürke nyilak jelzik a szélirányt).
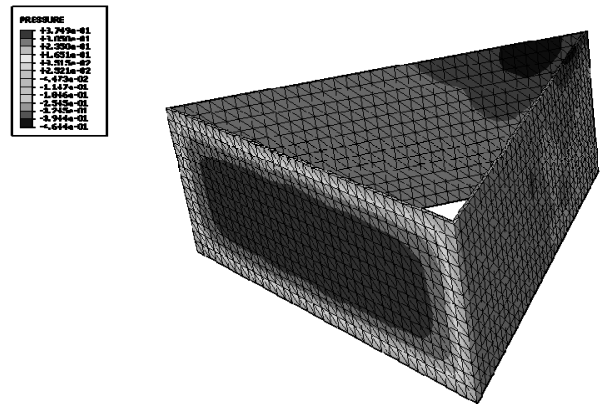

4. ábra. Az első terhelési esetben bekövetkezö nyomáseloszlás.

A szél irányát a vizsgált szerkezet tengelyére merőlegesen vettük, így 3 terhelési eset adódott (3. ábra): az egyik oldalra merőlegesen, az egyik oldallal párhuzamosan, illetve csúcs felől (hátsó oldalra merölegesen). A numerikus vizsgálatot az Abaqus CAE programcsomag segítségével végeztük, FC3D4 (4 csomópontos tetraéder) típusú elemeket használva.

A szélből származó nyomások értékeit az érvényes előírás (CR 1-1-4-2012) szerint számítottuk ki. Amennyiben $0,7679 \mathrm{kPa}$ értékű dinamikus szélnyomást alkalmazunk, az érvényes elöírás szerint egy elszigetelten álló téglalapú panelre $78,664 \mathrm{kN}$ eredő erő jut.

A modellezésből eredő nyomáseloszlás a 4. ábrán látható. A turbulens légáramlat az 5. és 6. ábrán van szemléltetve.

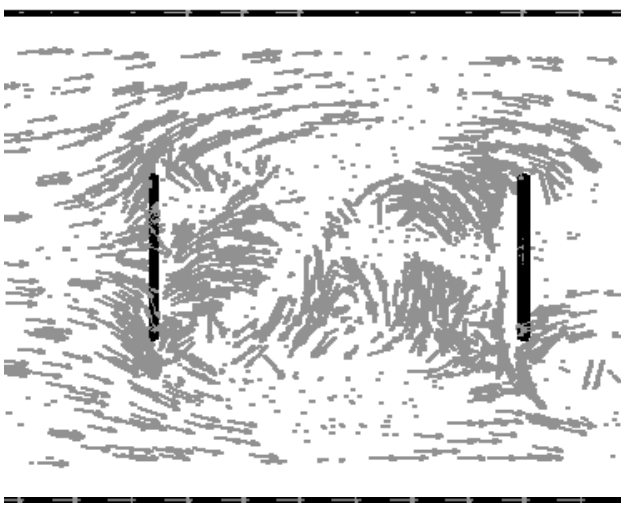

5. ábra. Turbulens légáramlat oldalnézetben, a panelek között (elsö terhelési eset).

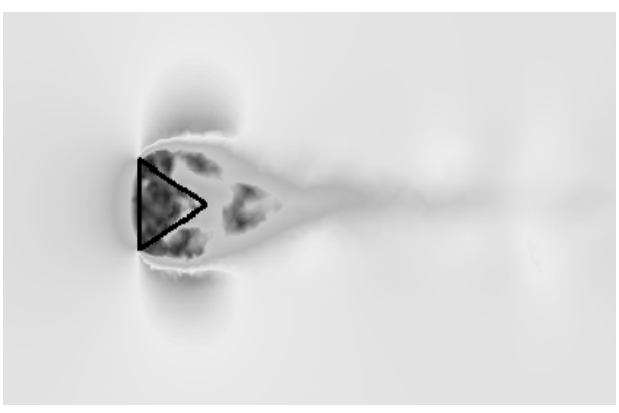

6. ábra. Turbulens légáramlat felülnézetben (elsö terhelési eset).

Az eredményként kapott eredő erők változása a három terhelési esetre a 7. ábrán van ábrázolva. 


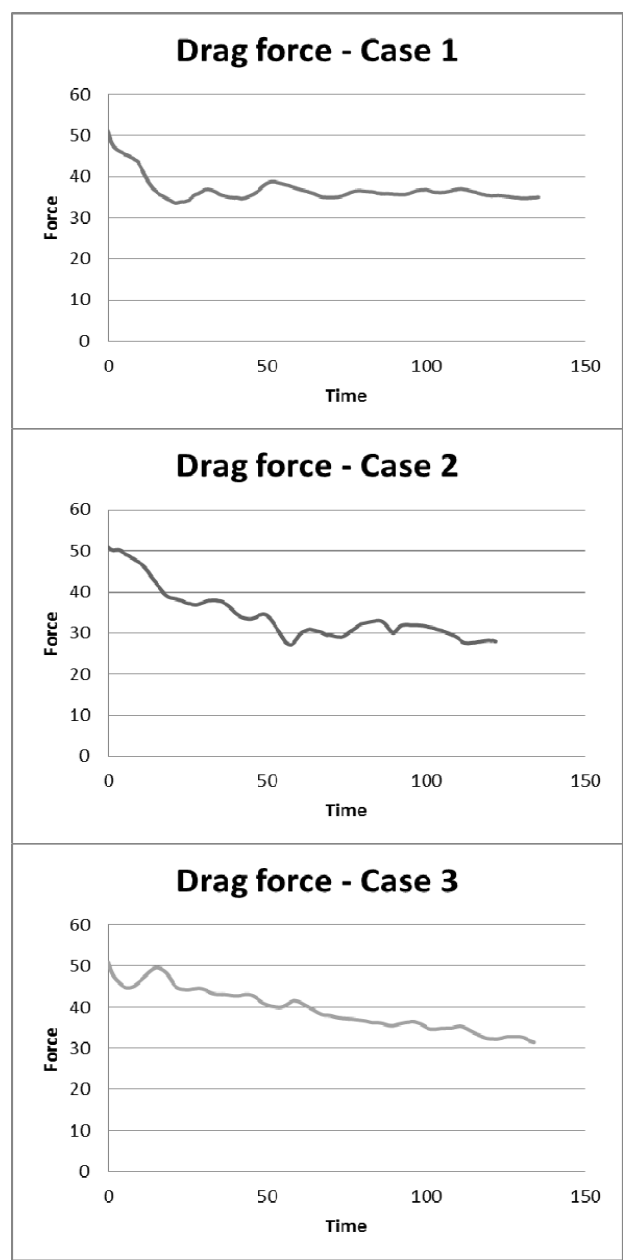

7. ábra. A kiszámitott eredő erők változásai a három terhelési esetben.

A vizsgálat időtartama 120 másodperc volt mindhárom esetben. Észre lehet venni, hogy az eredő erők mérete nem haladja meg az érvényes elöírás szerint számolt értéket.

\section{Következtetések}

A három említett terhelési esetet összehasonlítva, az elsőnél (egyik oldalra merőleges szélirány) jelentkeztek nagyobb számított értékek a vizsgálat során (4-6. ábrák). Bár a tervezéshez ajánlott eredő erő nagyobb mint a numerikus szimulációból származó, a valóságban lehet, hogy kisebb hatás érvényesül a merevítések, meg a másodlagos szerkezeti elemek miatt a szerkezetre.

\section{Szakirodalmi hivatkozások}

[1]Smith, D. A.; Zuo, D.; Mehta, K. C.: Characteristics of wind induced net force and torque on a rectangular sign measured in the field. Journal of Wind Engineering and Industrial Aerodynamics, Elsevier, vol. 133, 2014, 80-91.

[2]Zuo D.; Smith, D. A.; Mehta, K. C.: Experimental study of wind loading of rectangular sign structures. Journal of Wind Engineering and Industrial Aerodynamics, Elsevier, vol. 130, 2014, 62-74.

[3]Letchford, C. W.: Wind loads on rectangular signboards and hoardings. Journal of Wind Engineering and Industrial Aerodynamics, Elsevier, vol. 89, 2001, 135-151.

[4] Shademani, R.; Ghadimi, P.; Zamanian, R.; Dashtimanesh, A.: Assessment of Air Flow over an Equilateral Triangular Obstacle in a horizontal Channel Using FVM. Journal of Mathematical Sciences and Applications, Science and Education Publishing, Vol. 1, No. 1, 2013, 12-16.

[5]Agrwal, N.; Dutta, S.; Gandhi, B. K.: Experimental investigation of flow field behind triunghiular prisms at intermediate Reynolds number with different apex angles. Experimental Thermal and Fluid Science, Elsevier,, vol 72, 2016, 97-111.

[6]Bielecki, A.; Barszcz, T.; Wójcik M.: Modelling of a chaotic load of wind turbines drivetrain. Mechanical Systems and Signal Processing, Elsevier, vol. 54-55, 2015, 491505. 